\title{
8. The business of governing: building institutional capital in an urban enterprise
}

\section{Diane Smith}

In the wider community, people who have a business idea and the means to develop their idea can develop their own enterprise at their own initiative. It is not as straightforward in Aboriginal communities. This is because Aboriginal people are invariably members of wider family groups and communities, and individuals are not completely free to undertake private enterprise ... Similarly, opportunities are frequently seen as communal assets - belonging to clan groups or to communities, not to individuals ... Indigenous social and cultural imperatives often result in the creation of decision-making and ownership structures that make enterprise ownership and management inefficient, unwieldy, impossible ... Indigenous decision-making structures are about social and political representation, whereas optimum business decision-making should be about expertise, experience, knowledge and talent.

(Ah Mat 2003: 6)

The notion that all indigenous communities are the same is another of the myths or misunderstandings that has made its way into the policy and psyche of successive governments. Indigenous communities are diverse ... Diversity is not only in terms of language groups, clans or country, it goes further. Some communities may see economic growth as their primary goal, while others may accord more importance to cultural richness and taking care of country. It is important that differing indigenous traditions and values be recognised and accommodated in a way that contributes to building strong communities rather than undermine them.

(Armstrong 2007: 75-6)

\section{Introduction}

Behind the interest in Indigenous community governance lies a concern for the improved socioeconomic well being of Indigenous people. International research has found that there is a 'development dividend' (see Kaufmann 2005) attached to what is commonly referred to as 'good governance', and that it applies to quite poor countries and Indigenous societies (see Cornell and Kalt 1990; Kaufmann, Kraay and Mastruzzi 2005). In Australia, Indigenous communities 
are familiar with the cycle of business and economic development failures, and there is evidence that weak governance capacity is a contributing factor (Hunt and Smith 2006, 2007). In other words, Indigenous economic development is a governance issue.

The prime issue addressed in this chapter is whether there are particular kinds of organisational governance that might facilitate Indigenous economic success. The governance factors that impede Indigenous economic success have been extensively documented in Australia, to the point where there appears to be a public fixation on a deficit model of Indigenous economic development (see Dodson and Smith 2003 for a summary). This chapter focuses on the forms of organisational culture, governance representation, institutional frameworks and decision-making that facilitate rather than undermine economic success. This concern goes to the heart of 'who' should be the relevant Indigenous actors in the governance of economic initiatives, and the extent to which 'governing for business' should reflect Indigenous cultural values, relationships and systems of authority.

In Australia, these are hotly contested matters. The Indigenous commentators whose quotes open this chapter highlight one of the biggest challenges for Indigenous Australians in their governance arrangements today-namely, mediating the considerable tensions, expectations, and contemporary myths surrounding the role of 'community' and 'family' in Indigenous societies and their economic development. Many stakeholders agree with Richard Ah Mat above, that the social and cultural imperatives which are part of Indigenous family and community life are problematic for the kind of governance that is thought necessary for generating successful businesses and other economic development outcomes. Others identify 'family' and 'community' as potential sources of social and cultural capital, but ones that need to be strategically managed and 'balanced' within an organisation's governance arrangements and business objectives.

Indigenous organisations attempting to operate businesses seem to be particularly vulnerable. Their viability as businesses can be quickly eroded, not only by divisive conflicts created by community and family politics, but also by the unrealistic demands of government and the private sector, which hold their own ideological views about the role that 'community' and 'family' should and should not play in governance and economic development. For urban organisations and leaders engaged in business enterprises, key areas of vulnerability and challenge include:

- negotiating what constitutes 'the community' and 'family' in the light of historical resettlement, ongoing high rates of mobility, and the often tangled web of urban relationships and land-ownership rights; 
- negotiating processes of representation and decision making that support their economic goals, at the same time as building the internal and external legitimacy of their governance;

- responding to the diverse views and cultural values that Indigenous people have about their community, families and their governance needs;

- balancing Indigenous calls for more inclusive 'community' participation in, and access to, the services and benefits provided by organisations, alongside the hard-headed decision making and corporate governance required for economic success;

- responding to government pressure for 'whole-of-community' participation and representation, in circumstances where the community may be heterogeneous or fragmented; and

- negotiating the funding labyrinth of governments, and their underlying assumptions that 'urban communities' have 'easier' access to mainstream services, infrastructure, employment and economic opportunities.

This chapter looks at the establishment and operation of an urban Indigenous organisation in Newcastle - the Yarnteen Aboriginal and Torres Strait Islanders Corporation (YATSIC) - and how it has tackled the challenges of 'governing for business' within a complex community and economic setting. Yarnteen Corporation has a reputation for outstanding business and service delivery success that has been sustained over a 20 year period. Its Indigenous leaders have instigated specific strategies in respect to 'family' and 'community' when designing a governance model for the organisation. The paper proceeds by first unpacking the two social institutions of 'family' and 'community' —in both their broader Indigenous and Newcastle specific contexts - and then examines the corporation's governance solutions to these.

Importantly, Yarnteen's leaders have consciously constructed an internal governance culture and institutional environment to support its economic functions and goals. The organisation's economic success is directly related to these strategies. Specifically, Yarnteen has built up a foundation of institutional and governance capital that invests it with resilience, practical capacity, and business flexibility that is 'paying a development dividend'. It appears to have done this without forsaking its cultural identity as an 'Aboriginal organisation in the Newcastle community'. This is a considerable achievement given the difficulties highlighted by Richard Ah Mat, which seem to have contributed to the failure of so many other Indigenous community organisations and businesses.

\section{The problem with 'community' and 'family'?}

The concept of the 'Indigenous community' remains fuzzy and confusing. It continues to be associated with discrete geographical settlements, where it evokes ideas of a shared, idealised culture and a unity of purpose and action among its 
members (see Peters-Little 2000). In this way, 'community' and a homogeneity of culture and interests have come to be conflated in the public mind.

But this is not the case. A 'community' can be defined as a network of people and organisations that are linked together by webs of relationships, cultural identity, traditions, rules, shared histories, or simply common interests and goals (Hunt and Smith 2006, 2007). Indigenous communities are diverse in their cultures, historical experiences, governance histories and location. In Indigenous Australia, communities include not only discrete remote locations and rural settlements (of which there are over 1000; see Taylor 2006) but also 'communities of identity' whose members share a common cultural identity but are residentially dispersed across a region or set of locations. There are also Indigenous 'communities of interest' comprising different groups who unite for a common purpose, but may have different cultural identities and rights (see Hunt and Smith 2007: 4; Smith 2005: 24-5).

Today, approximately three-quarters of Indigenous Australians live in urban areas, with 30 per cent residing in major cities (Taylor 2006). While some are permanent residents of particular towns, many others are periodic urban dwellers who travel between towns and their hinterland rural communities, where they make use of a series of 'usual residences'. The high population turnover associated with this pattern of movement between cities and rural communities is such that Indigenous people in the city are not just similar to those in country areas - to a large extent they are the 'same' people spatially displaced at different stages of their lives' (Taylor 2006: 3). In other words, reference to 'urban Indigenous communities' needs to be qualified in terms of their mobility, cultural heterogeneity and contemporary social complexity.

Many Indigenous Australians have built up strong historical attachments to particular urban residential 'hubs', ${ }^{1}$ which have become an integral part of their contemporary identities. The resident Indigenous 'community' in such locations is not homogenous. More often, it comprises a mixed constituency of large extended families and related individuals, who come and go. These families form social networks within their urban location that stretch outwards to connect to other family members and 'communities' in surrounding regions (see Macdonald 2000; Peters-Little 2000: 412; Smith 2000; Sutton 1998). As a consequence, there are usually many 'communities' within a community, and extended families invariably form the foundations for these.

The governance of these fluid and compositionally complex urban communities is extremely challenging. A contributing factor has been the tidal wave of organisational incorporation that has occurred over the past 30 years. Today,

\footnotetext{
${ }^{1}$ Sometimes these 'hubs' are discrete communities. But they also include pastoral stations, fringe camps, and suburbs and neighbourhoods within towns and cities that have a long historical association by particular Indigenous groups and families.
} 
there are an estimated 5000 incorporated community and regional organisations across Australia, with an estimated (minimum) 30000 governing board members at their helm. ${ }^{2}$ To some extent, this growth has been the result of a large number of government agencies taking an interest in Indigenous corporate affairs and socioeconomic outcomes. However, it has also been the product of Indigenous agency and choice, as small urban Indigenous groups, and more recently regional alliances of urban organisation and communities, have sought greater autonomy and control in the conduct of their community affairs, delivery of services, and business and enterprise development.

While there have been important practical, political and funding advantages to incorporation, some organisations have become silos of factional power in communities, competing with each other for members and local legitimacy, as well as scarce funds, resources and staff. The well documented result is that community organisations can find themselves subject to debilitating internal conflict, poor governance and financial management, and are sometimes at odds with their own membership and each other.

This situation has been exacerbated by the lack of national policy clarity about who these urban organisations are supposed to represent and how they are to be governed. Are different governance arrangements needed for organisations that deliver community services, as opposed to those operating business enterprises? As Leah Armstrong highlights in the opening quote to this chapter, an overly simplistic view of 'community' has become entrenched in government policy, program and funding frameworks, where it is equated with the expectation that there should be a collective, community-wide basis to service delivery and the distribution of any benefits flowing from government funding. This has flowed through to expectations about the governance of organisations which have been tagged by governments as being 'community organisations'. These are subject to idealistic expectations that they will have 'community representation', 'community participation', engage in 'community consultations' and so on. ${ }^{3}$

Governments and the private sector commonly prefer to deal with local organisations that are 'representative' in this manner. They then look to these organisations to speak for and make decisions on behalf of 'the community', when this is invariably a highly fluid, mixed set of sub-groups. Even

\footnotetext{
2 Approximately 2500 Indigenous organisations are incorporated under the Corporations (Aboriginal and Torres Strait Islander) Act 2006 (CATSIA), each of which is encouraged to have a maximum of 12 directors (see Office of the Registrar of Aboriginal and Torres Strait Islander Corporations 2007). In addition, there are approximately an equal number of Indigenous corporations incorporated under state and territory incorporations laws.

3 See for example, the long list of reports from government reviews and inquiries over the last three decades; perhaps most prominently set out in various reports by the House of Representatives Standing Committee into Indigenous Affairs.
} 
organisations set up to represent a specific location, or sub-group within a location, are still expected to treat their members as a community of like-minded people with similar interests, goals and priorities. Under such institutional conditions, governments have promoted the 'community' as a benchmark for fair representation, equitable distribution of resources and benefits, proper consultation, the source of legitimacy, and the rightful recipient of 'downwards' accountability.

Hand in hand with the murky concept of community goes that of 'family'. While the important role of extended families in the domestic economies and social systems of Indigenous communities is well documented (see Finlayson 1991; Macdonald 2000; Smith 2000; Sutton 1998), it is not clear to what extent (or how) they might provide a positive basis for governance and economic development. Indeed, it is commonly asserted that Indigenous family relationships are highly problematic for good organisational governance and undermine economic development outcomes. The family is viewed according to a dysfunctional, deficit model, not as a form of contemporary social and economic capital.

Yet the notion of 'family' has long been the central ordering principle within Indigenous Australian societies, both in their traditional and contemporary modes. Invoked in almost every context and in every discussion, 'family' is the core unit, at both an actual and conceptual level, in Indigenous social and economic life (see Smith 2005; Sutton 1998). In particular, the extended family is the primary residential form, with each individual's investment in family relationships widely distributed across expanding networks of relatedness.

Today, families of polity (cf. Sutton 1998) form the backbone of Indigenous communities and many local organisations, thereby linking an extended family group identity to organisational identities and forms of political representation. In this manner, extended families not only have a form of internal governance, they are also embedded into other layers of governance at community and regional levels, and outwards.

So, why is it that family participation in governance and the business arena is seen so negatively? Increasingly, Indigenous families in communities have come to be associated with images of organisational nepotism and corruption, disputation and violence, debilitating factionalism, self-interested decision making, insular thinking and low business expertise. The transformation of the Indigenous family from a positive to a negative symbol has a long history in Australian colonialism. ${ }^{4}$ In recent times, its image has further deteriorated under

\footnotetext{
4 See Edmunds (1990) for an account of the impacts of colonisation on Indigenous family life and socialisation practices; Smith (1991: 5-6) for a summary of some of the key colonial interventions in Indigenous families and the increasingly negative portrayal of family life and relationships; and also
} 
public and media criticism of family violence and dysfunction in some communities, and their role in poor organisational management and governance. In regard to the latter, a report by the Office of the Registrar of Aboriginal Corporations (ORAC) $)^{5}$ found that:

The matter that Indigenous people make the most complaints to ORAC about is 'nepotism' within Indigenous corporations. Unmanaged nepotism has many adverse consequences, including high disputation, and will undermine an otherwise functioning program and corporation. It is a risk that funding agencies need to manage well. A key to managing it is understanding what it means and agreeing when action by the funding agency is necessary. Nepotism is widely understood to mean advantages obtained through family relationships, and is not necessarily illegal (ORAC 2004: 19).

The involvement of families in enterprise and commercial projects is seen as especially problematic. The Indigenous family lies at the heart of values of reciprocity, mutual responsibility and obligation. Because of this, it is argued that these institutional rules of family life cannot be trusted in the world of capitalism, business management and profit making. The family has thus become positioned as the antithesis of accountability, transparency and fairness; a form of 'cultural virus that infects economic development' (Ah Mat 2003: 3). For many stakeholders, 'community' is posed as the preferable unit for a more legitimate, inclusive form of governance, and for generating economic development.

There is certainly a plethora of evidence documenting the negative impacts of family politics on organisational governance, community life, and business success. But is that the whole story? Does family involvement in economic development initiatives and governance arrangements have to operate as a deficient cultural institution? Do core Indigenous values and relationships have to be entirely excluded from the governance of economic development initiatives in order for them to be successful? Can the two be reconciled? The experience of Yarnteen Corporation provides evidence for some alternative conclusions and options.

\section{Community and organisational governance in Newcastle}

With a population of 146000 , the industrial town of Newcastle on the central coast of New South Wales (NSW) is the second largest town in the state. According to 2006 Census results, around two per cent of its residents are Indigenous. The Aboriginal 'community' largely comprises families who resettled

Daly and Smith (2003), in which the 'deficit' and 'asset' views of families are considered in respect to their impact on the well-being of Indigenous children.

5 As of 1 May 2008, this Australian Government office is now called the Office of the Registrar of Indigenous Corporations (ORIC). 
in the town several decades ago, who have strong, continuing cultural ties both to the town itself and to surrounding rural communities and families across NSW (Ball 1985; Hall and Jonas 1985; Jonas 1991; Smith 1996, 2005). There is also a small group of Torres Strait Islanders living and working in the town, who have links to Islander communities in northern Queensland and the Torres Strait. An early survey of Indigenous households in the town carried out in the mid 1980s by the local Awabakal Cooperative reported that 75 per cent of those households were from outside the area (Hall and Jonas 1985). This movement into Newcastle created an estimated 700 per cent increase in the city's Indigenous population over the twenty years between 1971 and 1991 (Arthur 1994).

Importantly, amidst this flow of people there is a stable core of family members who have called Newcastle home for over four decades. These 'immigrant' families were instrumental in establishing the early Aboriginal service delivery organisations and local Aboriginal land councils in the town and surrounding region. Recent assertions of a local native title claim by an Indigenous family in the town, as well as the proliferation of traditional owner groups in the larger Newcastle-Hunter Valley region in recent years, have inserted issues of 'land ownership' versus 'historical' residence into the wider community dynamics. To date, there has been no native title land returned in the Newcastle town area.

The Aboriginal 'community' of Newcastle is therefore compositionally complex, comprising numerous extended family groups who have their Indigeneity in common, but who have family histories and relationships that link them to different resettlement phases, different cultural identities, and different regional communities. The so-called Newcastle 'Indigenous community' is in fact a network of dispersed nodes of governance in the form of organisations, senior leaders and key families. Some strands of the network are more closely connected than others.

It is not surprising then that there is no single 'community' governing body. Rather, the Indigenous residents in Newcastle are represented by an extremely large number of organisations based in the town and surrounding Hunter Valley region. ${ }^{6}$ Some organisations are required to be widely representative under their statutory rules, while others are associated with particular families or service needs. There are community tensions that occasionally erupt into disputes over services and the governance of organisations, and which spill into attempts by different groups to 'take over'. At the same time, there are also positive relationships between a number of the families and organisations whose senior leaders meet regularly at forums and community events, forming an influential

\footnotetext{
${ }^{6}$ The Arwarbukarl Cultural Resource Association Inc (which operates out of Yarnteen) recently produced a 'Directory of Indigenous Organisations and Government Services in the Hunter' that listed over 60 different Indigenous service delivery organisations, see $<$ http://www.arwarbukarl.com.au/default.aspx? id $=27>$.
} 
peer network in the town. A number have worked for decades at regional, state and national levels on Indigenous political, governance and policy issues.

The formation of the Awabakal ${ }^{7}$ Aboriginal Co-operative Ltd in 1976 was a pivotal event in creating a sense of Aboriginal identity in Newcastle. 'The co-op' was established as a response to the unmet service and employment needs of the growing number of Aboriginal people who had migrated to the town in the 1960-70s. It focused on community development initiatives and started several long-standing housing, health, welfare, economic and training initiatives.

The co-op also played an extremely important role as the incubator of other organisations that play an important role in the town today. Because some 'younger' organisations have been incubated out of older, apical organisations there is, in effect, a 'genealogical connection' between groups of organisations who support each other's work and goals. Yarnteen is an influential node in this urban network.

\section{Yarnteen - a quiet economic success}

Yarnteen Corporation has a long-standing reputation for both its business success and community development outcomes on several fronts. It successfully runs a major bulk warehousing and bagging facility for grains, protein meal and fertiliser - Port Hunter Commodities — which commenced trading in 1994. This venture commenced with one warehouse and bagging plant, and now has three state-of-the-art warehouses with storage capacity for 70000 metric tonnes. It succeeded in gaining accreditation from the Australian Quarantine Inspection Service to conduct 'cleaning' of non-compliant imports, making it the only warehousing operation to do so in the port area.

In 1992, the corporation was one of the first urban organisations to operate a Community Development Employment Projects (CDEP) scheme, and it provided a range of social and cultural services and economic development opportunities for Aboriginal and Torres Strait Islander residents of the town and the wider Hunter River region (Smith 1996). It was one of a small number of CDEP organisations to subsequently participate in 2001-02 in the Australian Government's Indigenous Employment Centre trial, ${ }^{8}$ successfully placing 20 people into full-time work and then going on to become a fully-fledged Indigenous Employment Centre.

\footnotetext{
7 'Awabakal' is the spelling of the name for the traditional land-owning group of the Newcastle area, which was used by the founding leaders of the co-operative when it first formed in 1976. At that time, it was thought that no representatives of the original traditional group remained. The leaders of the co-operative adopted the name as a mark of respect for the traditional lands and culture of that group. Recently, a native title claim has been made by extant members who are asserting traditional ownership, and a contemporary linguistic orthography has developed that spells the same name as 'Arwarbukarl'. ${ }^{8}$ See Champion (2002) for an account of these employment trials.
} 
Subsequently, Yarnteen received a CDEP 'Achievement Award for Innovation' from the Australian Government in recognition of the advances it made in the use of technology to network CDEP organisations. ${ }^{9}$ More recently, the organisation has consistently been on the front foot in responding to the recent radical changes to the CDEP scheme.

From the beginning, an integral part of its economic and employment initiatives has been the provision of in-house training, professional development and case management support to individuals. The corporation recently established the Indigenous Creative Enterprise Centre. This enterprise addressed the 'digital divide' by offering the Indigenous community in Newcastle access to computers and technology for skills and small business development. It has provided financial support and professional mentoring to the Arwarbukarl Cultural Resource Association. This is a dedicated cultural organisation whose main activities are 'protection and continual practice and teaching of our culture and the revival of the local Awabakal language' (YATSIC 2005). More recently, Yarnteen has expanded activities into small business training functions.

In 2006, Yarnteen extended its business portfolio by opening a car wash business in Port Macquarie. It aimed to capitalise on the growing demand to conserve water in areas under restrictions and provide a customer friendly car wash service. It sought the most recent technology - this time from the United States of America - to develop 'green' water recycling processes.

Yarnteen Pty Ltd was also created to operate as a property investment vehicle that enables the corporation to build an asset base for future investments. It currently owns land and warehouses at the Newcastle Port, 100 acres at Wollombi that it operates as a cultural and conference camp accessible to all Newcastle's Indigenous residents, and major residential property and buildings in town and interstate.

\section{Yarnteen's governance history}

Different institutional elements (such as norms, values, policies, regulations and routines) evolve as a product of the unique governance history of each organisation. These internally sourced institutions govern the behaviour of an organisation, its leaders and staff.

Not surprisingly, the governance history of Yarnteen Corporation has both urban and rural influences. Like many other Aboriginal organisations in the Hunter region, Yarnteen had its beginnings in the Awabakal Co-operative. An early internal review by leaders of the co-op led to several of its functional programs being 'farmed out' to organisations that were set up to take on the program roles.

\footnotetext{
9 Under a prestigious partnership it negotiated with Microsoft Australia, Yarnteen developed an innovative website to assist networking and best practice exchange between CDEP organisations.
} 
These organisations were incubated and mentored by the co-op until they became independent service delivery organisations in their own right.

Yarnteen was one such incubated organisation, becoming incorporated in June 1991. The leadership of the Awabakal Co-op stayed closely involved in mentoring the early development of Yarnteen and its emerging leadership. This process of organisational mentoring and incubation has in turn become a signature feature of Yarnteen's development.

While the corporation's purpose and objectives evolved over the years in keeping with its growth, there has always been a strong focus on economic development at the heart of its operations. Reflecting back on the organisation's governance history, Yarnteen leaders identify several 'key factors that influenced [its] governance structure' right from the beginning (pers. comm.; see also YATSIC 2005). The two founding leaders (one Aboriginal, the other Torres Strait Islander) say they were particularly keen to make an enduring change for the better in the economic circumstances of their families. They wanted greater economic independence for their own families and, in that way, to act as an economic role model for the wider Indigenous community: 'From the first, our organisation stressed its desire to become a full agent in our own development' (YATSIC 2005).

In order to do this, the leadership felt strongly that:

the governance structure was ... an important strategy to achieve the long-term objectives and economic self sufficiency of the organisation. Our number one priority was to have a governance structure that was sensitive to and compatible with the culturally [sic] diversity and interests of our community, but importantly that offered stability and contributed to good governance rather than undermining it (Armstrong 2003).

In particular, we aimed to create a balance between economic and social obligations for greater community capacity building ... Our goal to empower Indigenous individuals and organisations to achieve self-determination is being achieved through our governance structure (YATSIC 2005).

From the beginning, a first-order consideration in designing Yarnteen's organisational governance was a recognition amongst the founding Awabakal and corporation leaders 'that the Indigenous community around Newcastle area is made up of many different family and clan groups ... who have resettled in the region in search of better employment opportunities' (YATSIC 2005). They wanted to avoid the problems that other organisations had experienced with open-ended, amorphous community participation leading to unwieldy representative structures, and to focus on a core group of families with whom they had well-established connections. They had also witnessed first hand the 
debilitating effects of community politics on the governance of earlier NSW co-operatives and Local Aboriginal Land Councils. These organisations were regarded as having 'lost' valuable financial assets and economic ventures because of factionalised disputes over membership, representation, and community access to benefits.

The organisation's leaders also wanted to create 'a balance between economic and social obligations for greater community capacity building'. However, they also 'held the view that focusing only on the social aspects of people's lives may not produce lasting changes to individual families or communities' (YATSIC 2005). They clearly 'recognised the importance of business in supporting a healthy community' (cf. Jonas 1991: 12).

This positive assessment of the potential role of family, in tandem with their reservations about a 'whole of community' approach to business, and a desire to secure a strategic balance between cultural, social and economic goals, has set the tenor of Yarnteen's governance and institutional operations since 1991.

\section{Yarnteen's governance model}

Yarnteen's founding leaders believed that culturally-based decision making processes could form an effective basis for governing arrangements, but within a tight representative model. The leaders identified a core set of large extended families with long-term ties to Newcastle as the organisation's main membership group. They proceeded to establish the organisation's system of governing representation, decision making and membership around this particular subset of the wider community.

Given the problems, expectations and misunderstandings associated with the notion of family representative models in organisational governance, it is useful to examine how Yarnteen managed the potential negative impacts and built upon the positives in its governance for economic development. And furthermore, how it addressed the external pressure for wider community participation and access to its economic success.

The organisation stresses that it does not purport to represent the whole Aboriginal community of Newcastle. It did not feel bound to seek its board representatives from across the diversity of groups residing and travelling through the town. It did, on the other hand, see itself as having a broad community development remit in many of its service delivery functions, several of which are accessible to all Indigenous residents. These functions are not seen as necessitating the inclusion of the whole community into its representative structure. As a senior leader on the board noted: 'It's ok to have one group of people cooking the cake, if everyone else eventually gets a slice of it'. Yarnteen's leaders saw their commitment to deliver particular cultural, employment and training services to the wider community as part of their ability to spread some 
of the benefits of their economic success more widely, but without jeopardising their business viability.

These seemingly contradictory strategies - the one business, the other community/cultural - have been operationalised within the organisation's governance and institutional environment. In 1991, a Yarnteen Management Committee was established which represented four major extended family groups who had resettled in the Newcastle-Hunter region and 'adopted' the town over several decades. At that time, the organisation acknowledged that the traditional landowners of the region were the 'Awabakal', even though when it was first established none were thought to remain. The Management Committee started with 10 members, and is now called the Yarnteen Board. New representatives on the board are nominated and selected from the core member families. The board oversights the business and some of the cultural initiatives of Yarnteen, but these functions are differently structured.

The corporation's governance model for board representation and 'membership' for its economic ventures is tightly circumscribed to the core group of extended families. Its community development initiatives, on the other hand, are more inclusive and focus on its wider community 'constituency', which is the wider Newcastle Indigenous population. These residents can access and benefit from a range of 'community' initiatives and services provided by the organisation. The 'community' services operate out of separately incorporated organisations, under the umbrella of Yarnteen Corporation. The boards of these organisations also have a wider set of representatives on their governing boards.

In effect, Yarnteen's leadership designed separate approaches to its 'membership' and its 'constituency'. The organisation's members are the core families, and they stand at the heart of board membership and are the beneficial members of the economic ventures. Its constituents are drawn from the wider community, and are the people to whom cultural, employment, training and other social services are directed. This distinction appears to have been extremely beneficial in helping to quarantine the economic arm of the organisation from its other functions.

However, as a consequence of the tight governing structure created for its business ventures, the organisation has been seen in some quarters of the Newcastle Indigenous community and by some government departments as being 'exclusive', unrepresentative and 'not a community organisation'. But in light of its transparent governance strategy for economic success and its diverse delivery of community services, this is clearly not the case. However, these assertions highlight the considerable pressure that governments can apply to Indigenous business organisations to be 'whole-of-community' and how they equate this with 'good governance'. It also highlights the pressures that arise from within the wider Indigenous community when some groups feel that a 
local organisation should distribute its economic benefits more widely to all residents of the community. Neither of these expectations is applied to non-Indigenous private sector businesses in Newcastle.

The tight family representative model appears to have directly contributed to remarkable stability within the governing board. Eight out of the current 10 people are foundation members of the organisation. There have been significant benefits for the organisation as a result of this representative stability. One important advantage appears to be the creation of considerable governance 'capital'. For example:

- board members have been able to build a strong shared commitment to the organisation's long-term economic vision;

- the board is seen to have considerable legitimacy in the eyes of its members and staff;

- a solid foundation of trust and openness has been progressively developed within the board;

- there is a collegial relationship of partnership and honesty between the board and senior management (many of whom are also long-term employees of the organisation);

- a decision-making process has developed over time that is familiar and reliable; and

- board members can fall back on their history of consensus-building and experience of having resolved problems.

Stability is not only a feature of the governing board, but also of management and staff. Several senior staff members have been employed for as long as the original board members. Of the 37 people employed full-time in 2003-04 (YATSIC 2005), 29 were Indigenous and eight non-Indigenous, which is evidence of a very high level of Indigenous participation and employment. This figure includes 24 males and 13 females - with women represented in management as well as office staffing areas.

With such stability of leadership and staff an organisation could easily settle into a convenient comfort zone in its governance and business initiatives. Yet Yarnteen seems to have been able to avoid the associated pitfalls of insularity, narrowing expertise, failing performance, and resistance to change. It has also designed a set of effective buffers against potential family factionalism, disputes and self-interested decision making, which have been evident in other organisations with tight family-based representative models. The implementation of a four-pronged strategy appears to have been influential in achieving these outcomes, and includes the development of: 
- $\quad$ structural flexibility and diversification;

- a strong, internal governance culture;

- diverse and deep institutional capital; and

- accountable, professional leadership.

\section{Structural flexibility and diversification}

Over the years as Yarnteen has grown, it has retained operational flexibility by routinely reviewing its strategic direction and diversifying its structure to respond to changing economic and commercial conditions. The corporation adopted an 'incubation strategy' to facilitate the establishment of offshoot organisations, which have taken over specific functional parts of its operation.

For example, in 2004, Yarnteen undertook an internally instigated review of its governance, organisational structure and functions. As a result, it decided to minimise possible risk to its business enterprises, whose assets were identified as being open to potential 'social stripping' by broader community constituents, and to the risk of the potential failure of any of the organisation's more community oriented services. As a result of that review, the corporation set up two separately incorporated organisations with their own boards - Youloe-ta Indigenous Development Association and Yamuloong Incorporated Association-to deliver their community-based employment and training services.

Youloe-ta now manages the original Yarnteen CDEP scheme and operates the Indigenous Employment Centre. It also runs a conference facility, an Aboriginal bush foods centre for school groups, and training and employment mentoring services. At one stage, along with Yamuloong, it was a wholly-owned subsidiary of Yarnteen.

Yamuloong Association was established as an Aboriginal Registered Training Organisation to provide nationally accredited training in business administration, small business mentoring, and information and technology training. It was subsequently re-incorporated into Youloe-ta after another Yarnteen-initiated review determined that it required better corporate support.

These separately incorporated bodies have continued to retain close links with the corporation. This group of organisations refer to themselves collectively as the 'Yarnteen family of organisations' or 'the Yarnteen group' (see Fig. 8.1) and includes Port Hunter Commodities Pty Ltd, Riverside Car and Boat Wash, Indigenous Creative Enterprise Centre, and Yarnteen Pty Ltd as wholly-owned subsidiaries, plus the incubated offshoots. 
Fig. 8.1 The 'Yarnteen family' of organisations

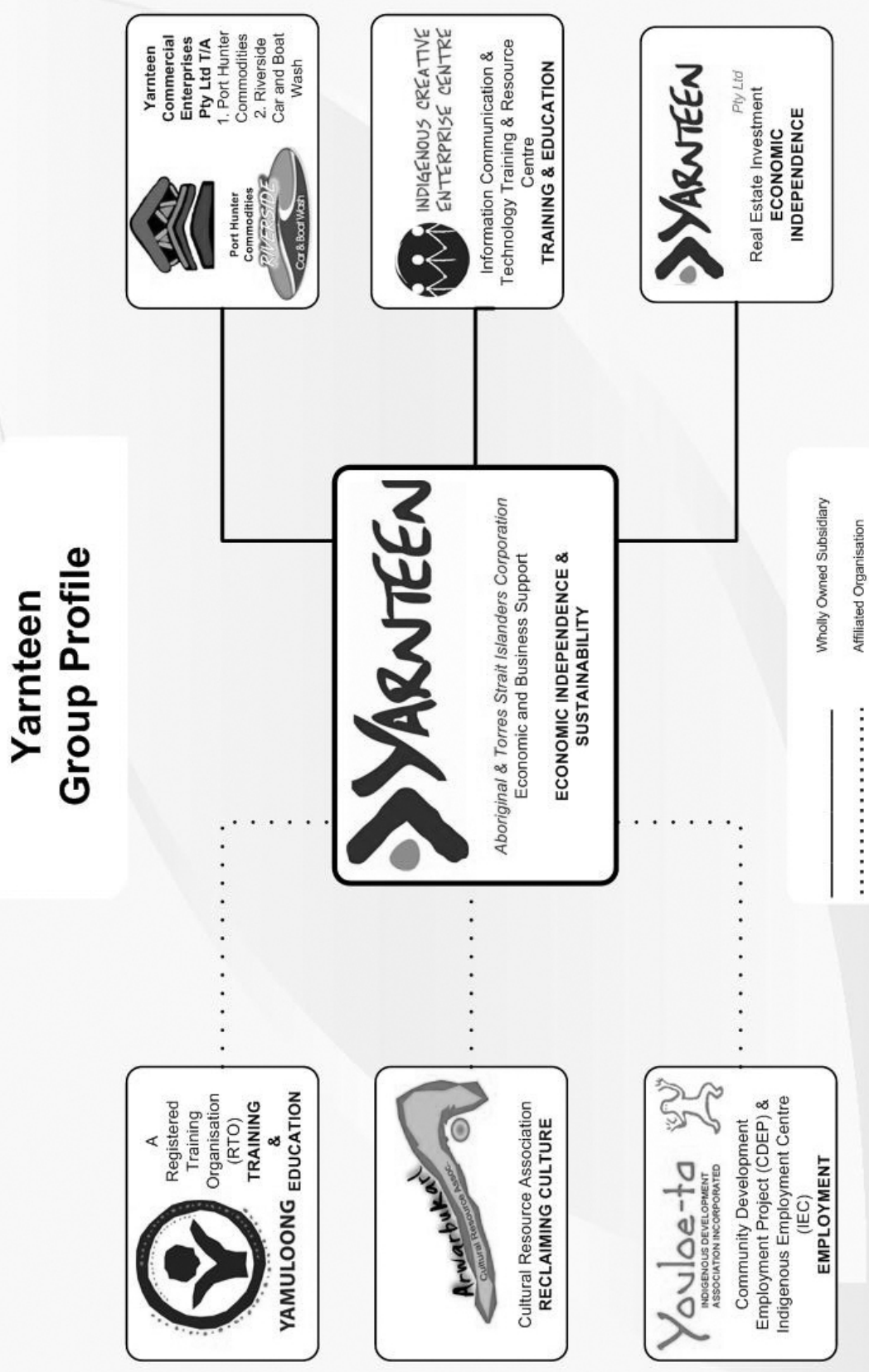

Source: Yarnteen Aboriginal and Torres Strait Islanders Corporation 
Over the course of its operations, Yarnteen has also assisted Newcastle Aboriginal residents with business start up, operational advice and mentoring. These incubated enterprises have included: an Indigenous housing construction company, a transport company, cultural tourism accommodation, and a plumbing business. These operate as self-employed businesses.

This alliance of organisations comprises a networked governance model. Yarnteen Corporation acts as a 'hub', maintaining a valued relationship of mentoring, management support and financial advice for the incubated offshoots. At the same time, as mentioned above, it has legally quarantined its economic ventures from potential financial liability and stripping by retaining them as wholly-owned subsidiaries. The incubated organisations have separate boards on which there is representation from the Yarnteen Board, but a majority of other community members.

This strategy of 'planned organisational devolution' and 'strategic incubation' reinforces the demarcation of Yarnteen's economic pursuits alongside its partnership approach to community service-delivery and cultural goals.

It is noteworthy that the cultural metaphor of 'family' has been used as a model for developing this form of devolved, networked governance. A major advantage of this model lies in its flexibility, its tolerance of a diversity of identities, its capacity to extend close working relationships to new components, and the benefits of inter-dependency - in much the same way as extended families do in Indigenous communities.

The relationship between the incubated organisations and the 'mother' corporation is seen by both staff and leaders as being flexible and egalitarian. The groups cooperate for particular purposes, but each regards itself as undertaking valued functional roles and responsibilities over which it has autonomy. This type of networked governance operates like a close coalition of autonomous parts and appears to be well suited to undertaking business in parallel with separate community functions.

\section{A durable governance culture}

Yarnteen has exceptionally good corporate governance. The organisation is accorded legitimacy by external stakeholders and regulators-it has passed government-instigated reviews and financial audits, and continues to receive favourable assessments from the private sector. An annual report is published each year, and has been since its inception. Its administrative systems and planning processes are kept straightforward and are understood by staff and governing members, and management and staff are qualified in a range of skills and professional in their conduct.

The Chair of the Yarnteen Board convenes well run, minuted meetings, and board members say they are properly provided with clear information and 
considered advice by the Executive Director and Chair. There appears to be consistent attendance at meetings by board members. Their collective view is that there is a proper focus on the big issues during meetings, and that individual members come along prepared to do their job. A factor in the effectiveness of the board's decision making is that the members are confident in the accuracy of the financial information and strategic business advice they are provided. Board members ensure they understand the complex financial matters brought before them by consistently asking questions of management, and discussing potential business risks and options.

A primary factor in building these governance skills for business has been the provision by the Executive Director of ongoing, in-house training for board members on issues including their financial roles and responsibilities, business planning, risk management, consensus decision making, and board practice. In collaboration with the Executive Director, the board has developed a 'Board Values Statement' that seeks to promote the members' shared commitment to transparent, honest decision making, fairness, and internal and external accountability. As a consequence of these internal professional development initiatives, the board is familiar with strategic financial planning and their business transitions appear to be well managed (see Smith 1996, 2006).

The separation of powers between the board and Executive Director is generally understood and implemented, contrary to many Indigenous organisations. But importantly, the Yarnteen approach to this 'good governance' prescription remains a flexible one. There is a close working relationship of mutual support between the board and senior management. Individual board members also collaborate with staff on more operational tasks, and staff members periodically contribute to strategic planning and goal setting for the organisation. In other words, the governance arrangement could more accurately be described as 'separate, but working together'.

This 'governance partnership' is somewhat contrary to the standard principle that proposes a much stricter division between the roles and responsibilities of boards and management. Yet Yarnteen's approach seems to enable it to make better combined use of its knowledge, skills and experience across the layers of the organisation. This has promoted resilience and a strong shared commitment within the organisation.

Board members and senior management also espouse a joint approach to balancing the need for both business innovation and stability - a philosophy that has been described by the Executive Director as 'restless self-renewal'. In these diverse ways, the organisation has developed a valuable reserve of corporate governance capital to sustain its economic goals, which can be called upon in times of planned internal transition or externally instigated change. 
Perhaps more importantly, though, alongside this corporate practice, Yarnteen's leaders have actively created a broader and durable 'governance culture' within the organisation, its subsidiaries and offshoots.

An organisation's 'governance culture' can be defined as the system of formal and informal traditions, collective values, and culturally-shared mechanisms for behavioural accountability, incentives and censure that direct staff, management and leaders to conform to the organisation's policies, vision and goals (see Bresser and Millonig 2003; Cornell and Kalt 1995; Hunt and Smith 2007). The formal components of an organisation's governance culture may include its written policy documents, dispute and appeal procedures, vision statements and strategic plans. Its informal aspects are typically unwritten, but nonetheless prevail in people's behaviour and interaction within the organisation; they tell individuals how to do things and how to relate to each other.

In practice, a great deal of what happens in organisational governance falls into this informal area. Informal governance works at the level of individuals, through processes such as how conflicts and appeals are mediated, praise and reward given, behavioural sanctions applied, collective identity reaffirmed, and through the style or personality of decision-making and management.

The leaders of Yarnteen have embedded a pervasive 'governance culture' within the organisation which actively promotes a particular set of norms. These include fairness, mutual respect, the value of personal contribution, accountability and teamwork in the work environment, and a shared commitment to the organisation's long-term success and autonomy. Importantly, these values are promoted in a manner that reinforces collective support for the style of governance as being distinctly Aboriginal and therefore legitimate.

This collective support is further reinforced by the prevalence of Aboriginal humour, a decision making style that resonates with Aboriginal consensus and conflict mediation processes, and the perception that all members of the organisation - from board members to young staff-are 'one family'. These characteristics are regularly articulated by people as valued qualities of the organisation's 'cultural identity' (Armstrong 2007: 75). And board members emphasise their desire to maintain this style of governance:

We make decisions like a washing machine. First we just push it all around, everything round and round and have a good talk about every part of it. Then we come to a decision. Once a decision is made, board members think it is important to stick to it ... then we agree as one. Once a decision is passed, that's it, it's finished. Then we're under one agreement, we get on with it (Yarnteen Corporation Board member).

This governance culture does not simply sit at the top with the Yarnteen Board and Executive Director; it has been seeded by the leadership throughout the 
management and staff, and the family of organisations. At the heart of this governance culture lies a process of institution building that has been deliberately embedded in Yarnteen's modus operandi.

\section{Building institutional capital}

Institutions can be defined as the 'rules of the game', the socially and culturally legitimated behavioural expectations that can be rewarded if followed, or sanctioned if violated. Rules and their related processes are the organising tools of governance. They tell the leaders, staff and members of an organisation how it should work, what decisions are made on behalf of members, and who may make them. Effective institutions are those that are capable of regulating and channelling both individual and collective behaviour.

Institutional weakness has been highlighted as a critical factor in the poor governance of many Indigenous organisations and governments (Cornell 1995; Hunt and Smith 2007; Sterritt 2002). In the case of Yarnteen, its leaders have created and sustained a range of governance institutions. These provide a system of incentives, rewards, constraints and limits, which direct the board, senior management and individual staff members to behave and perform in ways that support and strengthen the organisation's economic and service delivery objectives and strategies. Following Hunt and Smith (2007) and Oliver (1997), the richness or depth of this system creates a form of 'institutional capital' for Yarnteen.

In the context of economic development, institutional capital can be defined as the specific conditions in an organisation's internal and external institutional context that allow the formation of sustained business success and competitive advantage in the commercial arena (see Bresser and Millonig 2003: 225-2; and Scott 1995: 35-9). Scott (1995) and Bresser and Millonig (2003) distinguish three interacting components or pillars of institutional capital: regulative, normative, and cognitive. Each of these is applicable and evident in Yarnteen and its offshoot organisations.

Regulative institutions focus on rules (more often formal than informal) that are monitored and sanctioned in the case of possible corruption, bias, violation or poor corporate performance. To this end, Yarnteen's leaders have designed and implemented customised written policies, conflict resolution and appeals processes, procedures for the periodic review of individual performance, and regular internal reviews of its economic portfolio and community development functions. Senior and executive management participate in regular updates to monitor the organisation's commercial and corporate performance in respect to these.

These internal regulations are overwhelmingly seen as beneficial within the corporation, and so act as a source of institutional capital. Externally imposed 
government regulative mechanisms (such as mandatory government audits, departmental reviews, and financial and program reporting procedures) are invariably seen as overly burdensome and a source of erratic, but coercive pressure. The perception within Yarnteen is that the extent of regulatory scrutiny by government undermines its resilience and focus, rather than enabling its governance. The board and senior management of the organisation do give considerable attention to fulfilling their external compliance and financial responsibilities, but as the Executive Director notes, 'best practice organisations look to achieving this themselves and do not rely on external organisations to regulate or enforce this through external controls' (Armstrong 2003: 7).

Yarnteen's normative institutions comprise the norms and values which define the types of behaviours that are considered desirable, appropriate, and correct. The fact that these are uniformly seen as culturally legitimate by staff, management and board members means that they have deep acceptance and influence within the organisation. As a consequence, individual compliance with the organisation's codes of conduct, vision statement, the board's value statement and corporate responsibilities, and individual performance milestones, is considered to be both a behavioural and cultural obligation. The adoption and practice of a code of ethical values by the board is taken seriously as an example of the standards to be maintained by people throughout the organisation (see Armstrong 2003).

These normative institutions assist Yarnteen's leadership to modify structures, routines and business strategies as necessary, and so help to ameliorate potentially adverse affects that might arise from long-term board membership and employment of particular staff. Another influential aspect of the normative environment within the organisation is the expectation that members of the staff, management and board will routinely activate their networks into the wider business and public sector, and with regional Aboriginal communities. This further assists in preventing insularity of ideas and thinking.

The third element of Yarnteen's institutional environment is its cognitive capital. This relates to the ways in which individuals perceive and interpret their work and community life; a reality that is always a social and cultural construction. The cognitive institutional component of an organisation can be defined as the sum understanding of its internalised values and norms; that is, all the aspects of institutions that are taken for granted at a subconscious level.

Compared to the normative dimension, the cognitive component emphasises subjective assumptions, expectations and pressures. In this realm, Yarnteen has developed considerable collective cognitive capital shaped around members' close identification with its history, governance, goals and operation as a distinctly 'Aboriginal organisation', with Aboriginal values and behaviours, and 'family' relationships between the organisations. Within the corporation, 
these relationships and shared understandings are seen to positively facilitate success rather than undermine it.

The institutional strengths of the Yarnteen-regulative, normative and cognitive - are thus multidimensional and comprise both internal and external dimensions. Particularly influential institutions appear to be those that have been generated and embedded internally by the organisation's own leaders and staff, not those developed and imposed from outside.

These institutional strategies have taken time and commitment to implement. For many organisations they are the first things to go by the wayside when resources and people are stretched. Yet Yarnteen's rich institutional environment has generated considerable governance and economic benefits. Because they are shared and routinely followed by staff, management and board members alike, they become the vehicle for collective goal setting and action. The staff of Yarnteen say they feel part of this strategic institutional and governance approach and, as a consequence, a culture of teamwork and loyalty to the organisation has taken root. Not surprisingly then, in comparison with many other organisations, Yarnteen has had a very low turnover of employees and board members. Overall, its institution-building efforts are a form of capital that acts to buffer and neutralise the potential disadvantages of long-term board membership, select family representative structures, and debilitating external demands and pressures.

\section{Leadership for economic development}

The leadership of Yarnteen has been the catalyst for building the organisation's governance culture and institutional capital. In 2006, I carried out interviews and informal discussions with board members, the executive, managers and staff on the issue of leadership (see Smith 2006). The qualities of Aboriginal leaders seen to be necessary include:

- 'humility';

- 'being part of the Aboriginal community';

- 'having a passion for helping their community not just themselves';

- being 'selfless';

- 'having a vision of what's possible';

- 'experience in politics';

- being 'able to mentor younger people';

- 'able to talk to all kinds of people, and listen well'; and

- 'able to get agreement and consensus'.

Yarnteen's leadership is of a very high quality and has been a critical factor in the success of its governance for economic development. Its leaders are both male and female. They have strong links into the local and regional Indigenous community, and extensive networks into the state and national leadership. 
Several have national experience on representative organisations, councils and boards. They are extremely well qualified in their management, governance and financial expertise.

The Executive Director and Chair of Yarnteen have an extremely sophisticated understanding of governance best practice and strategies. The concept is frequently discussed in board meetings. Governance training has been provided in-house; senior managers have participated in external leadership workshops; several board members and senior managers have presented conference and workshop papers on the topic; and the Executive Director has undertaken the Australian Company Directors' Course. The combined effect is to ensure that the board is not easily swayed by any particular subset of family or factional interests, and takes considered economic risks. Single, strong voices cannot prevail against the board's collective assessment of issues, and there are robust guidelines for fair governance that members actively attempt to meet.

Leadership succession is currently an issue on the table for the organisation and it is starting to trial different strategies. The resilience of Yarnteen's governance culture and institutional capital is intimately associated with its current senior leadership. A future test for the organisation will be the extent to which its institutional capital assists it to weather the turnover of any key leaders.

\section{Conclusion: the business of 'governing for business'}

How do we live at this 'place' where the two worlds meet and remain Indigenous? Indigenous people want to participate in the wider economic, social and cultural lives that are enjoyed by other Australians. But they will not be successful and cannot be expected to succeed as long as they are denied the opportunities and the tools to enable cultural integrity and community survival (Leah Armstrong 2007: 75).

Yarnteen is an example of an organisation with effective, legitimate governance for economic development. It operates in a complex urban community environment and national context, where the challenges facing Indigenous businesses are substantial, and their corporate governance and financial failure is common. The Yarnteen family of organisations has an extremely high reputation in the wider private and public sectors, where it is seen to be a model for other organisations, and a sound investment opportunity. Its economic and strategic success is durable, and raises several important implications for other Indigenous organisations attempting to develop robust governance for sustained enterprise and cultural development.

First, the cultural 'self' in Yarnteen's governance is a complex pastiche that is a product of the Aboriginal history of Newcastle and its early organisations. This history is one of regional mobility and resettlement, long residence in the town by a core group of extended families, continuing strong cultural identities, and 
the incubation of a network of service delivery organisations in the town and surrounding region. The corporation's governance strategies and tactics have been based around understanding and managing both the constraints and benefits of that community environment and cultural identity.

Second, Yarnteen's leaders adopted a deliberate and effective strategy to insulate the organisation from debilitating community conflicts and jealousies by keeping its representative structure tight and sticking to its core enterprise development goals at the same time as ensuring that the organisation positively contributes to wider community cultural and social goals. In this way, the organisation manages to maintain a delicate balance between 'family' and 'community'. Alongside these structural strategies, the strength of its internal culture and institutional capital has enabled the corporation to create a set of workable limits and constraints on individual self-interest and family factionalism. Other organisations might consider the benefits that seem to flow from establishing a legal and structural demarcation between business and social/cultural initiatives, and from developing their governance representation and membership to support that distinction.

Third, fundamental to the organisation's economic success has been its internal governance culture and institutional capital. Effective governance is a prerequisite for mobilising other forms of capital and provides better conditions under which that capital can be developed and sustained. An organisation's institutional environment is a major driver of competitive commercial advantage. The leaders of Yarnteen Corporation have actively managed both their internal and external institutional contexts, and progressively built up deep reserves of regulative, normative and cognitive capital that have enabled it to remain proactive in assessing, taking up and managing economic opportunities.

And fourth, organisational leadership is essential if well designed governance and economic success are to be developed and sustained. Effective leaders are the fundamental drivers of institution building within an organisation. Without their commitment and demonstrated practice in this fundamental area, an organisation will lack the institutional environment that promotes flexibility, resilience and collective performance.

There is little doubt that it is the combination of governance, leadership, organisational flexibility, and institutional strength that has sustained this extraordinarily successful urban enterprise. Furthermore, in achieving this success the organisation has not had to turn its back on its cultural identity, its community and family relationships. Yarnteen not only works in an Aboriginal way, but also meets external demands for effective corporate governance, business standards and financial accountability. 


\section{Acknowledgements}

My research engagement with Yarnteen Corporation commenced in 1995 and focused on factors contributing to their success in operating the CDEP scheme. The research on which this chapter is based was conducted over several visits between 2006 and 2007.

During my visits, the board members, management and staff at Yarnteen provided me with enormous support and assistance in the collaborative research carried out under the umbrella of the ICGP. I would especially like to thank Leah Armstrong, Executive Director of Yarnteen, and Jim Wright, Chair of the Yarnteen Board, for the considerable time, intellectual contribution, research feedback, editorial comments, friendship and enthusiasm they gave to my research and this paper.

The members of the Yarnteen Board welcomed the opportunity to assess how they were travelling in respect to their roles and responsibilities. They happily made themselves available for lively discussions and have been frank in their feedback on my various reports. This has made the research process a pleasure.

Senior managers of Yarnteen contributed valuable time when they were under heavy workloads. I thank them for their professional approach to engaging in and supporting my work. I would also like to thank the many staff members of Yarnteen who spent hours assisting me to organise interviews, meetings and discussion sessions, and who tirelessly assisted me with access to data and written reports. In particular, I would like to thank Pat Capper for her unstinting support and assistance during my several stays, and Uncle Rex Morgan who took the time to show me around town and the surrounding region and give me his history of Yarnteen.

\section{References}

Ah Mat, R. 2003. 'The moral case for Indigenous capitalism', Unpublished paper presented to the Native Title Conference: Native Title on the Ground, 3-5 June, Alice Springs.

Armstrong, L. 2003. 'Financial management and business systems: the backbone of an effectively resourced capacity for governance', Unpublished paper presented to the Building Effective Indigenous Governance Conference, 5-7 November, Jabiru, NT, available at <http://www.nt.gov.au/cdsca/ indigenous_conference/web/html/papers.html> [accessed 19 May 2008].

2007. 'Finding Australia's soul: rebuilding our Indigenous communities', The Circle, 1: 74-6, Social Ventures Australia, available at $<$ http://www.socialventures.com.au/files/pdf/TC\%20mag\%20Leah\% 20Armstrong.pdf> [accessed 19 May 2008]. 
Arthur, W. S. 1994. 'The same but different: Indigenous socioeconomic variation', Unpublished report to the Australian Institute of Aboriginal and Torres Strait Islander Studies, Canberra.

Ball, R. E. 1985. 'The economic situation of Aborigines in Newcastle, 1982', Australian Aboriginal Studies, 1: 2-21.

Bresser, R. and Millonig, K. 2003. 'Institutional capital: competitive advantage in light of the new institutionalism in organisational theory', Schmalenbach Business Review, 55: 220-41.

Champion, M. 2002. 'Urban CDEPs as Indigenous Employment Centres: policy and community implications', CAEPR Discussion Paper No. 228, CAEPR, ANU, Canberra, available at <http://www.anu.edu.au/caepr/ discussion.php>.

Cornell, S. and Kalt, J. P. 1990. 'Pathways from poverty: development and institution-building on American Indian reservations', American Indian Culture and Research Journal, 14 (1): 89-125, also available at $<$ http://www.hks.harvard.edu/hpaied/pubs/pub_016.htm > [accessed 19 May 2008].

- and - 1995. 'Cultural evolution and constitutional public choice: institutional diversity and economic performance on American Indian reservations', PRS 95-3, Harvard Project on American Indian Economic Development, Malcolm Weiner Center for Social Policy, John F. Kennedy School of Government, Harvard University, Cambridge, MA.

Daly, A. and Smith, D. E. 2003. 'Reproducing exclusion or inclusion? Implications for the wellbeing of Indigenous Australian children', CAEPR Discussion Paper No. 253, CAEPR, ANU, Canberra, available at $<$ http://www.anu.edu.au/caepr/discussion.php $>$.

Dodson, M. and Smith, D. E. 2003. 'Governance for sustainable development: strategic issues and principles for Indigenous Australian communities', CAEPR Discussion Paper No. 250, CAEPR, ANU, Canberra, available at $<$ http://www.anu.edu.au/caepr/discussion.php $>$.

Edmunds, M. 1990. 'Doing business: socialisation, social relations, and social control in Aboriginal society. A review in relation to the issues underlying Aboriginal deaths in custody', Unpublished discussion paper prepared for the Royal Commission into Aboriginal Deaths in Custody on behalf of the Department of Prehistory and Anthropology, ANU, and AIATSIS, Canberra.

Finlayson, J. 1991. Don't Depend on Me: Autonomy and Dependence in an Aboriginal Community in North Queensland, PhD Thesis, Anthropology Department, ANU, Canberra. 
Hall, M. R. and Jonas, W. J. 1985. On the Fringes of Newcastle Society, Newcastle Aboriginal Cooperative Ltd, Newcastle.

Hunt, J. and Smith, D. E. 2006. 'Building Indigenous community governance in Australia: preliminary research findings', CAEPR Working Paper No. 31, CAEPR, CASS, ANU, Canberra.

- and 2007. 'Indigenous Community Governance Project: year two research findings', CAEPR Working Paper No. 36, CAEPR, ANU, Canberra.

Jonas, W. J. 1991. Awabakal, Bahtabah, Biripi, Worimi: Four Successful Aboriginal Organisations, Unpublished report, Aboriginal Education Unit, University of Newcastle, Newcastle.

Kaufmann, D. 2005. 'Back to basics: ten myths about governance and corruption', Finance and Development, 42 (3), available at <http://www.imf.org/external/pubs/ft/ fandd/2005/09/index.htm>.

Kaufmann, D., Kraay, A. and Mastruzzi, M. 2005. 'Governance matters IV: governance indicators for 1996-2004', World Bank Policy Research Working Paper 3237, available at <http://worldbank.org/wbi/ governance/pubs/govmatters4.html $>$.

Macdonald, G. 2000. 'Economies and personhood: demand sharing among the Wiradjuri of New South Wales', in G. W. Wenzel, G. Hovelsrud-Borda and N. Kishigami (eds), The Social Economy of Sharing: Resource Allocation and Modern Hunter-Gatherers, Senri Ethnological Studies 53, National Museum of Ethnology, Osaka.

Oliver, C. 1996. 'The institutional embeddedness of economic activity', Advances in Strategic Management, 13: 163-86.

Oliver, C. 1997. 'Sustainable competitive advantage: combining institutional and resource-based views', Strategic Management Journal, 18: 697-713.

Office of the Registrar of Aboriginal Corporations (ORAC) 2004. Report-Forum on Risk Issues for Programs Funding Indigenous Corporations, ORAC, Australian Government, Canberra.

Office of the Registrar of Aboriginal and Torres Strait Islander Corporations (ORATSIC) 2007. 'Duties of directors and other officers', Fact Sheet, October, Office of the Registrar of Aboriginal and Torres Strait Islander Corporations, Australian Government, Canberra, available at <http://www.oratsic.gov.au/about_ORIC/legislation/CATSI_Act.aspx\#6.

Peters-Little, F. 2000. 'The community game: Aboriginal self-definition at the local level', AIATSIS Research Discussion Paper No. 10, AIATSIS, Canberra. 
Scott, R. 1994. 'Institutions and organizations: toward a theoretical synthesis', in R. Scott and J. Meyer (eds), Institutional Environments and Organization: Structural Complexity and Individualism, Sage Publications, Thousand Oaks, CA.

1995. Institutions and Organizations, Sage Publications, Thousand Oaks, CA.

Smith, D. E. 1991. 'Toward an Aboriginal household expenditure survey: conceptual, methodological and cultural considerations', CAEPR Discussion Paper No. 10, CAEPR, ANU, Canberra.

-1996. 'CDEP as urban enterprise: the case of Yarnteen Aboriginal and Torres Strait Islanders Corporation, Newcastle', CAEPR Discussion Paper No. 114, CAEPR, ANU, Canberra.

(ed.) 2000. Indigenous Families and the Welfare System: Two Community Case Studies, CAEPR Research Monograph No. 17, CAEPR, ANU, Canberra.

-2005. 'Indigenous households and community governance', in D. Austin-Broos and G. Macdonald (eds), Culture, Economy and Governance in Aboriginal Australia, Sydney University Press, Sydney.

2006. 'Evaluating governance effectiveness: a facilitated process with the board of Yarnteen Corporation', ICGP Case Study Report No. 2, ICGP, CAEPR, ANU, Canberra.

Sterritt, N. 2002. 'Defining Indigenous governance', Paper presented to the Indigenous Governance Conference, 3-5 April, Canberra, available at $<$ http://www.reconciliation.org.au/igawards/pages/aboutgovernance/conference.php $>$.

Sutton, P. 1998. 'Families of polity: post-classical Aboriginal society and native title', in P. Sutton, Native Title and the Descent of Rights, National Native Title Tribunal, Perth.

Taylor, J. 2006. 'Population and diversity: policy implications of emerging Indigenous demographic trends', CAEPR Discussion Paper No. 283, CAEPR, ANU, Canberra.

Yarnteen Aboriginal and Torres Strait Islanders Corporation (YATSIC) 2005. Annual Report, YATSIC, Newcastle. 